\title{
IMPLEMENTASI PROGRAM KOTA TANPA KUMUH (KOTAKU) \\ (Studi di Kelurahan Bende Kecamatan Kadia KotaKendari)
}

\author{
Muhammad Arif Tanzil, La Ode Monto Bauto, Sarmadan \\ Jurusan Ilmu Kesejahtraan Sosial Fakultas Ilmu Sosial Dan Ilmu Politik \\ Universitas Halu Oleo Kendari \\ E-mail : muhammadariff571@gmail.com
}

\begin{abstract}
Muhammad Arif Tanzil (C1B3 15 017), the title of this thesis is The Implementations of Kota Tanpa Kumuh (KOTAKU) Program. It was studied in Kelurahan Bende Kecamatan Kadia Kota Kendari. First Consultant is Dr. H. La Ode Monto Bauto, M.Si and Second Consultant is Sarmadan, S.Sos, M.Si. The Objective of this study to: (1) Know the implementation of KOTAKU program in Kelurahan Bende Kecamatan Kadia Kota Kendari. (2) Know the benefit of KOTAKU program in Kelurahan Bende Kecamatan Kadia Kota Kendari. This researcher used qualitative approaches is approaches of researches that purposes to understand the deepest of the objects. The determination of informant on this research was used Purposive Sampling. Although the data that used quantitative, the resources was primer and secondary data. The technique of data in this research used interview, observation, and documentation. The technique of analysis was descriptive quantitative. The result of this research found that (1) The Implementation of KOTAKU program in Kelurahan Bende could be said going on effectively. This signed with the quality of some conditions of the implementation based on instructions of operational from KOTAKU program in poor society empowerment in the city area. It was activities on socialize quality in $R W$. The aims to invited the society, planning activities were defined and agreed priority zone, the quality of activities began by prepared was the team of firmly responsibility each program, then quality with push involved on the society, the continued was the team formed that to close of the society. To protect of program have been quality with evaluation of program to know the activities that necessary got on repaired. However, KOTAKU program that have been already go it: a. Physical program means rehabilitation of dirty residence. $b$. Non physical program means handled the rubbish, training or repairing environment of small/micro and medial work. (2) The quality of KOTAKU program has been given the benefit to the society in Kelurahan Bende. The benefits were preparing on residence and environment of the society, although it pushed the society to live with stand alone.
\end{abstract}

Keywords: Implementation, Benefit, KOTAKU, 


\title{
WELVAART
}

\section{JURNAL ILMU KESEJAHTERAAN SOSIAL}

\begin{abstract}
ABSTRAK
Muhammad Arif Tanzil (C1B3 15 017) Skripsi ini berjudul Implementasi Program Kota Tanpa Kumuh (KOTAKU) Studi di Kelurahan Bende Kecamatan Kadia Kota Kendari. Pembimbing I: Dr. H. La Ode Monto Bauto, M.Si. dan Pembimbing II: Sarmadan, S.Sos, M.Si. Penelitian ini bertujuan untuk: (1) Mengetahui implementasi program KOTAKU di Kelurahan Bende Kecamatan Kadia Kota Kendari.(2) Mengetahui manfaat program KOTAKU di Kelurahan Bende Kecamatan Kadia Kota Kendari. Penelitian ini menggunakan pendekatan kualitatif yaitu pendekatan penelitian yang bertujuan untuk memahami obyek secara mendalam. Penentuan informan dalam penelitian ini dengan cara purposive sampling. Adapun jenis data yang di gunakan dalam penelitian ini adalah data kualitatif dan data kuantitatif, sumber data yang di gunakan yakni data primer dan data sekunder. Tekhnik pengumpulan data dalam penelitian ini menggunakan tekhnik wawancara, observasi, dan dokumentasi. Tekhnik analisis data dalam penelitian ini di analisis secara deskriptif kualitatif. Hasil penelitian ini ditemukan bahwa (1) Implementasi program kota tanpa kumuh di Kelurahan Bende dapat dikatakan berjalan secara efektif. Hal ini ditandai dengan dilaksanakannya beberapa persyaratan implementasi menurut Petunjuk Teknis Operasional Program Kota Tanpa Kumuh dalam Pemberdayaan Masyarakat Miskin di Kawasan Perkotaan, yakni dilaksanakannya kegiatan sosialisasi yakni dilaksanakan di RW sasaran dengan mengundang masyarakat, kegiatan perencanaan yakni menentukan dan menyepakati kawasan prioritas, kegiatan pelaksanaan yang didahului kegiatan persiapan yakni pemantapan tim panitia penanggung jawab setiap program kemudian pelaksanaan dengan mendorong keterlibatan masyarakat, keberlanjutan yakni pembentukan panitia yang mendampingi masyarakat memelihara program yang sudah dilaksanakan serta evaluasi program agar dapat diketahui pelaksanaan kegiatan yang perlu mendapat perbaikan. Adapun program KOTAKU yang telah dilaksanakan : a. Program fisik menyangkut rehabilitasi pemukiman kumuh. b. Program non fisik berupa Pelatihan/penyuluhan penangan sampah, Pelatihan/penyuluhan perbaikan lingkungan, dan Pelatihan usaha mikro kecil dan menengah.(2) Pelaksanaan program KOTAKU telah memberikan manfaat bagi masyarakat di Kelurahan Bende. Manfaat tersebut disamping memperbaiki lingkungan pemukiman masyarakat juga mendorong masyarakat untuk hidup mandiri.
\end{abstract}

Kata Kunci: Implementasi, Manfaat, KOTAKU.

\section{PENDAHULUAN}

Upaya-upaya untuk tercapainya perbaikan kesejahteraan hidup bagi setiap individu maupun masyarakat luas, dalam pengertian sehari-hari seringkali disebut sebagai upaya "pembangunan". Dengan kata lain, pembangunan merupakan segala upaya yang terus-menerus ditujukan untuk memperbaiki kehidupan 


\section{WELVAART}

JURNAL ILMU KESEJAHTERAAN SOSIAL

masyarakat dan bangsa yang belum baik, atau untuk memperbaiki kehidupan yang sudah baik menjadi lebih baik lagi, Dalam pembahasan mengenai berbagai paradigm yang mencari jalan kea rah pembangunan yang berkeadilan, serta ketidakpuasan terhadap pelaksanaan teori-teori tersebut di negara-negara berkembang. Korten, 1984 memunculkan teori baru yang menyajikan potensipotensi baru yang penting guna memantapkan pertumbuhan dan kesejahteraan manusia, keadilan dan kelestarian pembangunan itu sendiri, yang kemudian disebut sebagai teori pembangunan yang berpusat pada rakyat(people centered development) (Mardikanto, 2012).

Salah satu upaya yang dilakukan untuk menanggulangi kemiskinan serta meningkatkan kehidupan sosial dan ekonomi, pemerintah menggunakan program Kota Tanpa Kumuh (KOTAKU) sebagai program lanjutan PNPM Mandiri Perkotaan. PNPM Mandiri Perkotaan, memiliki tujuan dan sasaran yaitu, terbangunnya lembaga di tingkat masyarakat yang berbasis universal kemanusiaan yang berorientasi pada pembangunan berkelanjutan. Kemudian meningkatnya akses bagi masyarakat miskin perkotaan terhadap pelayanan sosial, prasarana, hingga pendanaan untuk pengembangan usaha atau permodalan. Selain itu, dapat mendorong Pemerintah Daerah atau Pemerintah Kota agar semakin mampu memenuhi kebutuhan masyarakat miskin. Program KOTAKU (Kota Tanpa Kumuh) memiliki tujuan, diantaranya, menurunkan luas kawasan permukiman kumuh, kemudian membentuk Kelompok Kerja Perumahan dan Kawasan Permukiman (Pokja PKP) ditingkat kabupaten/kota. Dalam Program Kota tanpa kumuh diharapkan akan tersusunnya rencana penanganan kumuh tingkat Kota/Kabupaten dan tingkat masyarakat yang terlembagakan melalui Rencana Pembangunan Jangka Menengah Daerah (RPJMD). Meningkatnya penghasilan masyarakat Berpenghasilan Rendah (MBR) melalui penyediaan infrastruktur dan kegiatan peningkatan kualitas kawasan permukiman kumuh, serta terlaksananya aturan bersama sebagai upaya perubahan prilaku hidup bersih, masyarakat sehat, dan pencegahan kumuh (Asiah, 2016).

Kelurahan Bende Kecamatan Kadia Kota Kendari adalah salah satu Kelurahan yang menerima program KOTAKU di Kota Kendari, yangpelaksanaannya telah dimulai beberapa tahun lalu dan masih berjalan sampai saat ini. Program KOTAKU di Kelurahan Bende memiliki tujuan diantaranya untuk memberdayakan masyarakat sehingga dapat menanggulangi kemiskinan, meningkatkan kehidupan sosial dan ekonomi serta dapat menghindari luasnya kawasan permukiman kumuh. Sementara itu luas kawasan kumuh di kelurahan Bende masih tersisa seluas $17,50 \mathrm{H}$, a

Namun dalam penanganan kawasan kumuh di Kelurahan Bende diakui belum terlaksana secara maksimal, Untuk itu, Pemerintah di Kelurahan Bende terus berupaya meningkatkan kualitas penanganan kawasan pemukiman kumuh. Misalnya untuk periode 4 September sampai dengan 30 Oktober 2018, Pemerintah Kelurahan telah memprogramkan pembuatan jalan lingkungan dan drainase lingkungan di RT. 07 RW. 2 dan pembinaan program Kotaku dengan penerima manfaat sebanyak 28 Kepala Keluarga, menyusun rencana penanganan kawasan kumuh, sehingga diharapkan dapat meningkatkan keberdayaan masyarakat berpenghasilan rendah. 


\section{WELVAART}

JURNAL ILMU KESEJAHTERAAN SOSIAL

Disamping itu, pelaksanaan Program KOTAKU di Kelurahan Bende dilakukan secara bertahap untuk mengatasi persoalan yang dihadapi oleh masyarakat, terdiri atas; a) Masyarakat miskin, b) Kelembagaan masyarakat, c) Lingkungan. Alur kegiatan Program KOTAKU sesuai dengan Petunjuk Teknis Operasional, terdiri atas beberapa tahapan yaitu: 1) Perencanaan kegiatan, 2) Pelaksanaan kegiatan,3) Pengawasan, 4) Evaluasi. Untuk menghindari tumpang tindih dalam pelaksanaannya, alur kegiatan harus berjalan sesuai dengan tahapan yang ditetapkan dan dalam kondisi normal tidak boleh ada tahapan yang dilompati.Dengan alasan inilah sehingga penulis tertarik melakukan penelitian yang "Implementasi Program Kota Tanpa Kumuh (KOTAKU). (Studi di Kelurahan Bende Kecamatan Kadia Kota Kendari)."

\section{METODE PENELITIAN}

\section{A.Lokasi Penelitian}

Penelitian ini dilaksanakan di Kelurahan Bende Kecamatan Kadia Kota Kendari.Adapun alasan memilih lokasi penelitian ini karena Kelurahan Bende merupakan salah satu Kelurahan di Kota Kendari sebagai tempat pelaksanaan Program KOTAKU di Kelurahan Bende Kecamatan Kadia Kota Kendari.

Teknik penentuan informan ini dilakukan secara purposive sampling merupakan informan yang dipilih dengan tujuan dan pertimbangan tertentu.MenurutMoleong (2006), informan adalah orang yang dimanfaatkan untuk memberikan informasi tentang situasi dan kondisi latar penelitian. Jadi informan dipilih secara sengaja berdasarkan pertimbangan tertentu yakni mereka yang dianggap berkompeten, memenuhi persyaratan atau criteria untuk dijadikan informan yaitu kepala Kelurahan Bende, Ketua pengelola dan Sekertaris programKota Tanpa Kumuh (KOTAKU), Tim Pelaksana (2 orang) dan 5 orang penerima manfaat program Kota Tanpa Kumuh.

\section{B. Jenis Dan Sumber Data}

Data kualitatif, yang disajikan berupa deskriptif yaitu berdasarkan informasi dari para informan terhadap obyek yang akan diteliti. Serta data kuantitatif dalam menentukan jumlah informan serta memaparkan gambaran umum lokasi penelitian di Kelurahan Bende Kecamatan Kadia Kota Kendari. Dengan sumber data dalam penelitian ini yaitu sumber data primer dan data sekunder. Data primer, yaitu data yang diperoleh secara langsung dari peneliti dengan cara observasi dan wawancara dengan informan selama penelitian berlangsung, sedangkan Data sekunder, yaitu data penunjang yang diperoleh dari sumber-sumber tertulis berupa teori-teori yang relevan, hasil penelitian, gambaran umum lokasi penelitian.

\section{Teknik Pengumpulan Data}

Adapun data yang digunakan yaitu: Observasi atau pengamatan merupakan salah satu teknik penelitian yang sangat penting. Pengamatan itu digunakan karena berbagai alasan. Ternyata ada beberapa tipologi pengamatan.Terlepas dari jenis pengamatan, dapat dikatakan bahwa pengamatan terbatas dan tergantung pada jenis dan variasi pendekatan(Moleong,2007). Penulisakan melakukan pengamatan di Kelurahan Bende Kecamatan Kadia Kota Kendari untuk mengetahui permasalahan awal terkait permasalahan penelitian. Wawancara 


\section{WELVAART}

JURNAL ILMU KESEJAHTERAAN SOSIAL

yaitu Menurut Moleong, (2007) wawancara mendalam adalah percakapan dengan maksud tertentu. Percakapan dilakukan oleh dua pihak, yaitu pewawancara (interviewer) yang mengajukan pertanyaan dan pewawancara (interviewee) yang memberikan jawaban atas pertanyaan itu. Menurut Arikunto (2007) Peneliti harus mencatat teknik yang kondisi yang mana dan situasi yang mana mendukung penerimaan informasinya yang paling tepat. Dan Wawancara mendalam yaitu secara terbuka dengan mengarah pada persoalan penelitian. Peneliti melakukan wawancara dengan mendatangi informan di tempat tinggalnya atau ditempat yang telah disepakati dan Dokumentasi yaitu Menurut Arikunto (2007), dokumentasi yaitu mencari data berupa catatan, transkrip, buku, surat kabar, majalah, prasasti, notulen rapat, agenda, foto dan sebagainya serta Analisis dokumen yaitu mengumpulkan data yang bersumber dari arsip dan dokumen yang ada hubungannya dengan permasalahan penelitian.

\section{Teknik Analisis Data}

Teknik analisis data yang digunakan dalam penelitian ini adalah secara deskriptif kualitatif yaitu semua sumber data yang diperoleh dilapangan dikumpulkan dan kemudian ditarik kesimpulan berdasarkan hasil obsevasi dan jawaban-jawaban dari informan yang relevan dengan masalah-masalah dalam penelitian ini. Dengan langkah-langkah analisis data dalam penelitian ini yaitu Reduksi data merupakan proses pengumpulan data penelitian, seporang peneliti dapat menemukan kapan saja waktu untuk mendapatkan data yang banyak, apabila peneliti mampu menerapkan metode observasi, wawancara atau dari berbagai dokumen yang berhubungan dengan subjek yang diteliti. Maknanya pada tahap ini,sipeneliti harus mampu merekam data lapangan dalam bentuk catatan-catatan lapangan (fieldnote), harus ditafsirkan, atau diseleksi masingmasing data yang relevan dengan fokus masalah yang diteliti, serta penyajian data kepada yang telah diperoleh ke dalam sejumlah matriks atau daftar kategori setiap data yang didapat, penyajian data biasanya digunakan berbentuk teks neratif. Biasanya dalam penelitian, kita mendapatkan data yang banyak. Data yang kita dapat tidak mungkin kita paparkan secara keseluruhan. Untuk itu, dalam penyajian data peneliti dapat dianalisis oleh peneliti untuk di susun secara sistemtis, atau simultan sehingga data yang diperoleh dapat menjelaskan atau menjawab masalah yang diteliti. Dan Mengambil keputusan merupakan analisis lanjutan dari reduksi data,dan display data sehingga data dapat disimpulkan, dan peneliti masih berpeluang untuk menerima masukan. Penarikan kesimpulan sementara, masih dapat diuji kembali dengan data dilapangan, dengan cara merefleksikan kembali, peneliti dapat bertukar pikiran dengan teman sejawat, triangulasi, sehingga kebenaran ilmiah dapat tercapai.

\section{HASIL PENELITIAN}

\section{Gambaran Umum Lokasi Penlitian}

Letak Geografis Kelurahan Bende merupakan salah satu Kelurahan yang terletak dalam wilayah Kecamatan Kadia. Kelurahan Bende terletak di selatan ibu kota Kecamatan Kadia, jarak dari pusat pemerintahan Kecamatan adalah $6 \mathrm{Km}$ dan jarak dari pusat pemerintahan Kota Kendari adalah $1 \mathrm{Km}$. Dengan demikian dapat dipahami bahwa wilayah Kelurahan Bende menjadi salah satu sasaran 


\section{WELVAART}

JURNAL ILMU KESEJAHTERAAN SOSIAL

program KOTAKU karena menjadi salah satu wilayah perkotaan yang ada di Kota Kendari, dengan batas wilayah sebagai berikut Sebelah Utara berbatasan dengan Kelurahan Korumba, Sebelah Selatan berbatasan dengan Kelurahan Wowawanggu, sebelah Timur berbatasan dengan Kelurahan Lalolara, dan Sebelah Barat berbatasan dengan Kelurahan Kadia dan Kelurahan Poundambea.

Keadaan Iklim Kelurahan Bende memiliki Iklim Tropis dengan suhu udara rata-rata berkisar $29^{\circ} \mathrm{C}$ dengan suhu maksimum berkisar $33^{\circ} \mathrm{C}$. Pada bulan AprilOktober dengan curah hujan yang cukup tinggi, sedangkan pada bulan NovemberMaret curah hujan rendah dengan rata-rata berkisar 13,4 mm.

Pedoman Umum Program Kotaku di Kelurahan Bende, Kawasan perkotaan dan perkembangannya adalah sesuatu yang tidak terpisahkan satu sama lain. Kawasan perkotaan dengan komplesitas kegiatannya ini akan terus berkembang dari waktu ke waktu dan meliputi semua bidang pembangunan. Adanya perkembangan di kawasan perkotaan ini akan menjadi daya tarik tersendiri bagi masyarakat untuk berdomisili dan melakukan aktivitas kesehariannya beserta ekonominya di dalam kawaasan perkotaan tersebut. Hal ini mengakibatkan migrasi yang nantinya akan menambah beban perkotaan baik dari sisi ruang maupun intensitas aktivitas.

Meningkatnya jumlah penduduk dan intensitas aktivitas pada kawasan perkotaan ini perlu disikapi dan diantisipasi lebih awal oleh pemerintah daerah terkait. Hal ini perlu dilakukan mengingat fenomena tersebut dapat membangkitkan banyak persoalan perkotaan terutama yang terkait dengan ketersediaan dukungan permukiman dan infrastruktur perkotaan. Pembangunan permukiman dan infrastruktur perkotaan yang kurang atau belum mampu mengantisipasi serta mengakomodir perkembangan kawasan perkotaan akan menimbulkan persoalan antara lain: (a) tidak meratanya penyediaan infrastruktur perkotaan, (b) tidak tersedianya lingkungan permukiman yang layak, (c) pembangunan permukiman yang tidak terkendali pada daerah-daerah non permukiman, dan (d) permukiman kumuh. Meluasnya lingkungan permukiman di perkotaan dapat menimbulkan dampak pada peningkatan frekuensi bencana kebakaran dan banjir perkotaan, meningkatnya potensi kerawanan dan konflik sosial, menurunnya tingkat kesehatan masyarakat, menurunnya kualitas pelayanan prasarana dan sarana permukiman serta seringnya keluhan masyarakat miskin mengenai rendahnya kualitas lingkungan di tempat mereka bermukim. Melalui program Kotaku masyarakat merumuskan visi Kelurahan sesuai yang mereka harapkan, tatan kehidupan dan penghidupan yang mereka kehendaki sesuai kebutuhannya, kemudian menuangkannya dalam tata ruang kelurahan yang akan menjadi ruang hidup mereka yang baru. Masyarakat juga belajar menentukan dan melakukan deliniasi kawasan-kawasan permukiman yang menjadi kantong kekumuhan yang perlu segera ditangani melalui program KOTAKU. Visi dan misi penataan lingkungan permukiman di Kelurahan Bende didasarkan pada kondisi yang diharapkan secara realistis ideal, dengan memperhatikan kondisi wilayah, potensi, permaslahan, serta sistem nilai yang mendasari hakikat permukiman bagi kesejahteraan masyarakat dalam kerangka pembangunan berkelanjutan. Penentuan visi dan misi penataan lingkungan pemukiman di 


\section{WELVAART}

JURNAL ILMU KESEJAHTERAAN SOSIAL

Kelurahan Bende ditentukan berdasarkan musyawarah oleh kelompok-kelompok masyarakat berdasarkan cita-cita, harapan, potensi, dan permasalahan di lapangan.

Visi merupakan suatu pandangan ke depan yang menggambarkan arah dan pengelolaan lingkungan permukiman. Permukiman merupakan salah satu sektor strategis dalam upaya membangun masyarakat. Selain sebagai kebutuhan dasar manusia permukiman memiliki fungsi strategis dalam penyelengaraan pendudukan keluarga, perkembangan budaya dan peningkatan generasi mendatang yang berjati diri. Oleh karena itu,visi penataan lingkungan permukiman diarahkan untuk mendorong terwujudnya permukiman ideal yang layak dan mampu mewadahi aktivitas ekonomi masyarakat Melihat kondisi tersebutmaka visi penataan permukiman di Kelurahan Bende adalah ” terwujudnya Kelurahan Bende sebagai pusat perdagangan yang masyarakatnya berakhlak, adil, maju, dan demokratis menuju pencapaian kota dalam taman.

\section{Implementasi Program Kota Tanpa Kumuh (KOTAKU)}

Untuk memperoleh data yag akurat dalam menjawab rumusan masalah ada pada penelitian maka diperlukannya penjelasan tentang karakteristik informan yaitu nama, jabatan, dan penerima manfaat program Kota Tanpa Kumuh (KOTAKU) di Kelurahan Bende. Adapun Informan yang di ambil dalam penelitian ini adalah kepala Kelurahan Bende, Ketuapengelola dan Sekertaris programKota Tanpa Kumuh (KOTAKU), Tim Pelaksana dan penerima manfaat program Kota Tanpa Kumuh. Untuk lebih jelasnya dapat dilihat pada tabel berikut ini yang bersumber dari data informan:

Tabel 1. Jenis Kelamin Informan

\begin{tabular}{ccc}
\hline No & Jenis Kelamin & Jumlah \\
\hline 1 & Laki-laki & 8 \\
\hline 2 & Perempuan & 2 \\
\hline & & 10 \\
\hline
\end{tabular}

Sumber : Hasil Penelitian 2018

Berdasarkan data sekunder data sekunder yang diperoleh di lokasi menunjukkan bahwa implementasi program Kota Tanpa Kumuh di Kelurahan Bende lebih banyak laki-laki. Selain itu juga, jabatan dan penerima manfaat program kota tanpa kumuh (KOTAKU) di Kelurahan Bende Kota Kendari berbeda-beda, untuk lebih jelasnya dapat dilihat dari tabel berikut.

Tabel 2. Nama-nama dan jabatan serta penerima manfaat

\begin{tabular}{ccc}
\hline NO & NAMA & JABATAN \\
\hline 1 & Amir Yusuf S.Sos M.Sos & Kepala Kelurahan Bende \\
\hline 2 & Harjuna Nadjib & Ketua BKM Kelurahan Bende \\
\hline 3 & Santy & Sekretaris Kelurahan Bende \\
\hline 4 & Rahim & Tim Pelaksana KOTAKU Kelurahan \\
& & Bende \\
\hline 5 & Mahmud & Tim Pelaksana KOTAKU Kelurahan \\
& Bhmad & Penerima Manfaat Program KOTAKU \\
\hline 6 & &
\end{tabular}




\section{WELVAART}

JURNAL ILMU KESEJAHTERAAN SOSIAL

\begin{tabular}{ccl}
\hline 7 & Amiruddin & Penerima Manfaat Program KOTAKU \\
\hline 8 & Tahir & Penerima Manfaat Program KOTAKU \\
\hline 9 & Johriah & Penerima Manfaat Program KOTAKU \\
\hline 10 & Muslim & Penerima Manfaat Program KOTAKU \\
\hline
\end{tabular}

Sumber : Hasil Penelitian 2018

Program Kota tanpa kumuh (KOTAKU) hanya dapat dilihat dari jabatan dan penerima manfaat di Kelurahan Bende Kota Kendari dengan menangani permukiman kumuh untuk masyarakat yang kurang mampu sehingga dilakukan dengan melakukan perbaikan rumah berdasarkan program tersebut yang di ajukan oleh pemerintah untuk masyarakat kurang mampu.

\section{Tahapan-tahapan dalam pelaksanaan program KOTAKU}

Implementasi Program Kota Tanpa Kumuh (KOTAKU) di Kelurahan Bende Kota Kendari memiliki tahapan-tahapan dalam pelaksanaan program KOTAKU di Kelurahan Bende adalah tahap sosialisasi, tahap perencanaa, tahap pelaksanaan, tahap keberlanjutan, dan tahap evaluasi Adapun implementasi program Kota Tanpa Kumuh (KOTAKU) yaitu :

\section{A. Tahap Sosialisasi}

Ketika melaksanakan suatu kebijakan/program, sebelumnya harus didahului dengan sosialisasi. Seperti dipahami bersama bahwa langkah tersebut dimaksudkan untuk memasyarakatkan program, kemudian mengkomunikasikan program yang dijalankan kepada masyarakat kelompok sasaran sehingga langkah ini dapat menumbuhkan partisipasi masyarakat. Kegiatan sosialisasi ini dapat dilakukan dengan berbagai cara, misalnya dapat dilakukan secara langsung (melalui komunikasi tatap muka) atau dilakukan melalui media komunikasi baik cetak maupun media komunikasi elektronik. Dan sosialisasi programadalah setiap aktivitas yang ditujukan untuk memberikan pemahaman dan mempengaruhi masyarakat untuk mendukung program kotaku.

Berkaitan dengan sosialisasi kegiatan program Kota tanpa kumuh di Kelurahan Bende diungkapkan oleh Ketua BKM Kelurahan Bende bahwa bahwa program KOTAKU dalam tahap sosialisasi telah di sepakati bahwa masyarakat harus memahami program KOTAKU sehingga dalam pelaksanaannya dapat berjalan dengan baik. Hal ini sangat beralasan karena dapat meningkatkan partisipasi masyarakat.

\section{B. Tahap Perencanaan}

Perencanaan dalam program kota tanpa kumuh ditempuh dengan pelibatan dari berbagai pihak baik dari sisi pelaku maupun penerima manfaat. Dengan metode seperti itu diharapkan semua rencana yang dihasilkan dapat mengakomodasi semua kebutuhan masyarakat, selain itu dapat pulah digunakan untuk menyiapkan dukungan dari masyarakat saat program kota tanpa kumuh dilaksanakan. Serta konsep perencanaan program adalah menyusun pemecahan masalah bersama dan membangun komitmen pemangku kepentingan dalam penanganan permukiman kumuh.

Berdasarkan pengamatan sebelumnya pada, Nov. 2018 dan berdasarkan hasil wawancara Ketua koordinator BKM yaitu Harjuna yaitu tahap perencanaan program KOTAKU di tingkat Kelurahan harus mengacu pada Rencana Kabupaten Kota yang merupakan kesepakatan bersama mengenai penanganan permukiman 


\section{WELVAART}

JURNAL ILMU KESEJAHTERAAN SOSIAL

kumuh. Sedangkan wawancara bersama Bapak Ahmad Perencanaan tingkat kelurahan merupakan pertemuan masyarakat di Kelurahan yang bertujuan untuk membahas seluruh gagasan kegiatan hasil proses penggalihan gagasan ditingkat Rukun Warga. Bertindak selaku fasilitator Perencanaan adalah fasilitator kecamatan,fasilitator teknik kecamatan.

\section{Tahap Pelaksanaan}

Pelaksanaan kegiatan program kota tanpa kumuh merupakan tahap pelaksanaan seluruh rencanayang menjadi prioritas yang telahditetapkandalam musyawarah dalam suatu lingkungan masyarakat.. Beberapa hal yang dapat diamati dalam penelitian ini tentang pelaksanaan program kota tanpa kumuh di Kelurahan Bende yakni pada tahap persiapan pelaksanaan dan pelaksanaan kegiatan.

Persiapan pelaksanaan kegiatan program tanpa kumuh merupakan kegiatan pembahasanyang dilakukan mulai dari pelaku kecamatan sampai dengan pelaku tingkat kelurahanuntuk mempersiapkan pelaksanaan programprogram yang layak untuk dilaksanakan.

Dari pembahasan sebelumya dapat di pahami bahwa Konsep pelaksanaan programadalah implementasi kegiatan program kotaku sesuai dengan rencana yang disusun dalam dokumen perencanaan perkotaan. Berdasarkan data dilapangan dari berbagai pihak terkait pada , Nov 2018 serta wawancara dengan Bapak Amiruddin yaitu tahap persiapan kegiatan di dahului dengan pembentukan panitia, melengkapi berbagai dokumen yang di perlukan agar dalam tahap pelaksanaan dapat berlangsung sesuai yang di harapkan.

\section{Tahap Keberlanjutan Kegiatan}

Keberlanjutan kegiatan merupakan tahapan pasca pelaksanaan yang dikelola dan merupakan tanggung jawab masyarakat. Arah keberlanjutan kegiatan ialah membangun rasa memiliki masyaraka tdalam bentuk kemauan untuk memelihara hasil kegiatan sehingga manfaatnya memiliki nilai berkelanjutan.

Berdasarkan pengamatan sebelumnya pada nov,2019 dan juga wawancara bersama ibu santy yaitu program kota tanpa kumuh di Kelurahan Bende, setelah suatu program pelaksanaannya selesai, maka pemeliharaannya diserahkan kepada masyarakat penerima manfaat. Agar pemeliharaannya dapat dilakukan secara terkontrol maka dibentuk suatu tim pemeliharaan.

\section{E. Tahap Evaluasi Program}

Dalam Program Kota Tanpa Kumuh (KOTAKU), evaluasi dimaknai sebagai kegiatan melakukan pengamatan perkembangaan pelaksanaan suatu kegiatan yang dilakukan untuk memastikan apakah kegiatan yang telah dilaksanakan sudah terlaksana sesuai dengan tujuan dan sasaranyang telah ditetapkan.

Berdasarkan pengamatan bulan februari 2019 dan juga melakukan wawancara kepada satu Mahmud sebagai Tim Pelaksana KOTAKU Kelurahan Bende yaitu evaluasi dari pihak pemerintah selama ini berjalan dengan baik, dimana dalam pelaksanaan program KOTAKU selalu diiringi dengan kegiatan evaluasi sehingga dapat diketahui berbagai kegiatan yang perlu mendapat perbaikan. 


\section{WELVAART}

JURNAL ILMU KESEJAHTERAAN SOSIAL

\section{Manfaat Kegiatan Program Tanpa Kumuh}

Manfaat kegiatan program tanpa kumuh dibagi menjadi dua yaitu manfaat secara fisik, dan manfaat non fisik . manfaat program Kota Tanpa Kumuh (KOTAKU) yaitu :

\section{A. Manfaat Secara Fisik}

Berbagai program yang telah memberikan manfaat dalam masyarakat miskin di Kelurahan Bende yakni program perbaikan sarana dan prasarana, lingkungan pemukiman kumuh, sanitasi.

Berdasarkan diungkapkan oleh kepala Kelurahan Bende yaitu manfaat program KOTAKU di Kelurahan Bende bagi masyarakat yakni semakin berkurangnya kawasan kumuh. Pembangunan lingkungan fisik berupa perbaikan jalan setapak dan perbaikan saluran air serta program-program lainnya Program tersebut sangat dirasakan manfaatnya oleh mayarakat karena sebelumnya lingkungan mereka bila musim hujan banyak terlihat genangan air, sehingga terlihat lingkungan mereka kurang bersih, menyebabkan banyak masyarakat yang mengeluh. Dengan adanya program KOTAKU, keluhan dapat teratasi. Jalan setapak yang sebelumnya berlumpur jika musim hujan, saat ini keadaannya sudah menjadi lebih baik.

\section{B. Manfaat Non Fisik}

pelaksanaanprogram KOTAKUdiKelurahan Bende, dalam penelitian inijuga ditemukan beberapakeuntungandalam aspek non fisik berupa programprogram pengembangan sumber daya manusia. Seperti dipahami bahwa Sumber daya manusia (SDM) merupakan salah satu faktor yang sangat penting dalam program Kota tanpa Kumuh di samping faktor lain. Oleh karena itu, peningkatan SDM selalumendapat perhatian dengan baik. Manfaat dalam aspekSumber Daya Manusiadalam pelaksanaan program kota tanpa kumuh terutama dikalangan masyarakat penerima manfaat.

Berdasarkan di ungkapkan oleh Kepala Kelurahan Bende yaitu pelaksanaanprogram KOTAKUdiKelurahan Bende, dalam penelitian inijuga ditemukan beberapakeuntungandalam aspek pengembangan sumber daya manusia. Seperti dipahami bahwa Sumber daya manusia (SDM) merupakan salah satu faktor yang sangat penting dalam program Kota tanpa Kumuh di samping faktor lain. Oleh karena itu, peningkatan SDM selalumendapat perhatian dengan baik.

\section{KESIMPULAN}

Berdasarkan uraian yang telah dipaparkan sebelumnya mengenai Dari hasil pembahasan penelitian tentang implementasi program KOTAKU di Kelurahan Bende Kecamatan Kadia Kota Kendari dapat disimpulkan sebagai berikut :

a. Implementasi program kota tanpa kumuh di Kelurahan Bende dapat dikatakan berjalan secara efektif. Hal ini ditandai dengan dilaksanakannya beberapa persyaratan implementasi menurut Petunjuk Teknis Operasional Program Kota Tanpa Kumuh dalam Pemberdayaan Masyarakat Miskin di Kawasan Perkotaan, yakni dilaksanakannya kegiatan sosialisasi yakni dilaksanakan di RW sasaran dengan mengundang masyarakat, kegiatan perencanaan yakni menentukan dan menyepakati kawasan prioritas, kegiatan pelaksanaan yang 


\section{WELVAART}

\section{JURNAL ILMU KESEJAHTERAAN SOSIAL}

didahului kegiatan persiapan yakni pemantapan tim panitia penanggung jawab setiap program kemudian pelaksanaan dengan mendorong keterlibatan masyarakat, keberlanjutan yakni pembentukan panitia yang mendampingi masyarakat memelihara program yang sudah dilaksanakan serta evaluasi program agar dapat diketahui pelaksanaan kegiatan yang perlu mendapat perbaikan.Disamping itu, di penuhinya indikator nasional yaitu semakin berkurangnya kawasan pemukiman kumuh dan semakin meningkatnya kesadaran masyarakat untuk memelihara lingkungan. Adapun program KOTAKU yang telah dilaksanakan : a. Program fisik menyangkut rehabilitasi pemukiman kumuh. b. Program non fisik berupa Pelatihan/penyuluhan penangan sampah, Pelatihan/penyuluhan perbaikan lingkungan, dan Pelatihan usaha mikro kecil dan menengah.

b. Pelaksanaan program KOTAKU telah memberikan manfaat bagi masyarakat di Kelurahan Bende. Manfaat tersebut disamping memperbaiki lingkungan pemukiman masyarakat juga mendorong masyarakat untuk hidup mandiri.

\section{DAFTAR PUSTAKA}

Asiah, Imas (2016). Program Kota Tanpa Kumuh Kalibaru Dulu dan Sekarang. Direktorat Jenderal Cipta Karya.

AbuHuraerah, Abu. 2011Pengorganisaian dan Pengembangan Masyarakat: Model dan Strategi. Humaniora, Bandung.

Arikunto, S., 2007, Prosedur Penelitian Suatu Pendekatan Praktek EdisiRevisi VI hal 134, Rineka Apta, Jakarta.

Bungin, Burhan(2001) Metodologi Penelitian Kualitatif Dan KuantitatifYogyakarta:Gajah Mada Press

Faisal, Sanapiah. 2001. Format-Format Penelitian Sosial, Jakarta, PT. Raja Grafindo Persada.

Farida, Rina. 2016. Petunjuk Pelaksanaan Program Tanpa Kumuh (Kotaku) Tingkat Kabupaten/Kota. Direktur Pengembangan Kawasan Kumuh, Kementrian Pekerjaan Umum, Jakarta.

Kurniawan, J Luthfi at.al 2015. Negara Kesejahteraan dan Pelayanan Sosial.Intrans Publishing. Malang.

Mahendrawaty,

NanihdanAgusAhmadSafei. 2001.PengembanganMasyarakatIslam. Bandung, Rosda karya.

Mardiaknto, Totok dan Soebiato, Poerwoko. 2012. Pemberdayaan Masyarakat dalam Perspektif Kebijakan Publik. Alfabeta. Bandung.

Mulyasari, Gita. 2015. Kajian Partisipasi Perempuan terhadap Kegiatan Simpan

LexyJ.(2007)MetodologiPenelitianKualitatif,PenerbitPTRemaja RosdakaryaOffset Pinjam Perempuan (SPP) PNPM Mandiri di Kota Bengkulu. JSEP Vol 8 No.1 Maret 2015.

NoorIda Ruwaida. 2010. Pemberdayaan UKM Catatan Reflektif Hasil Meta Riset. Jurnal Sosiologi Masyarakat. Vol 15 no 1 Januari 2010 . 
Pokja Pengendali PNPM Mandiri. Website: www.pnpm-mandiri.org.

Purnomo, Agung T. 2013. Partisipasi Masyarakat Dalam Pemberdayaan Melalui Program PNPM Mandiri Perkotaan di Kelurahan Sekaran Kecamatan Gunungpati Kota Semarang, Semarang.

Qodrayati, Tri 'Ulya dan Fakhruddin, 2016. Kegiatan Simpan Pinjam Perempuan dalam Meningkatkan Keberdayaan Masyarakat Desa Kemloko Kabupaten Grobogan. Journal of Nonformal Education and Community Empowerment. 5 (2) (2016).

Sekretariat Pokja Pengendali PNPM Mandiri, http://www.pnpmmandiri.org/perpustakaan/buku/PNPM_Mandiri_Info_Kit_2012.pd $\underline{\mathrm{f}}$

Sumodiningrat, Gunawan. 2009. Mewujudkan Kesejahteraan bangsa Menanggulangi Kemiskinan. PT. Gramedia. Jakarta.

Suharto, Edi. 2005. MembangunMasyarakatMemberdayakanRakyat. PT. Refika Aditama, Bandung.

Suprastio, Ahmad. 2014. Implementasi Program Nasional Pemberdayaan Masyarakat Mandiri Pedesaan. Tesis. Universitas Wijaya Putra Surabaya.

Suyanto, Joko (2010), Gender dan Sosialisasi. Nobel Edumedia, Jakarta.

Wrihatnolo, Randy R. dan Riant Nugroho Dwidjowijoto. 2013. Manajemen Pemberdayaan Sebuah Pengantar dan Panduan untuk Pemberdayaan Masyarakat. Gramedia. Jakarta.

Zaputro, Wismoyo, Ade 2015. Implementasi Kebijakan Program Nasional Pemberdayaan Masyarakat (PNPM) Mandiri dalam Pengentasan Kemiskinan di Kecamatan Lembang Kabupaten Pinrang. Skripsi. Program Studi Ilmu Pemerintahan Fakultas Ilmu Sosial dan Ilmu Politik Universitas Hasanuddin Makassar. 